\title{
SYNTHESIS AND STRUCTURE-ACTIVITY RELATIONS IN THE CLASS OF 2-(PYRIDYL)PENEMS
}

\author{
A. Bedeschi, G. Visentin, E. Perrone, F. Giudici, F. Zarini, \\ G. Franceschi, G. Meinardi, P. Castellani, D. Jabes, R. Rossi \\ and C. Della Bruna
}

Farmitalia Carlo Erba SpA, R. \& D., Infectious Diseases Dept., Via dei Gracchi 35, 20146 Milan, Italy

(Received for publication June 12, 1989)

\begin{abstract}
The isosteric $\mathrm{CH} \rightarrow \mathrm{N}$ substitution in the class of 2-arylpenems results in improved antibacterial activity, with retention of the favorable characteristic of stability towards renal dehydropeptidase. High therapeutic efficacy was demonstrated in experimental mice septicemias with the 2-(3-pyridyl) derivative $\mathbf{2 b}$ and its orally absorbed acetoxymethyl ester prodrug $\mathbf{4 n}$.
\end{abstract}

Recently we described a series of penems differing from our previous 2- $\mathrm{CH}_{2} \mathrm{X}$ series in the interposition of a $p$-phenylene spacer between the nucleus and the $\mathrm{CH}_{2} \mathrm{X}$ group ${ }^{1)}$. Originally, we synthesized some simple 2-arylpenems ( $\mathbf{1} \mathbf{a}$ and $\mathbf{1 b}$ ) and found that they are characterized by excellent renal dehydropeptidase (DHP-I) stability and remarkable oral bioavailability (Table 2). These favorable properties had to be set against poor activity against most Gram-negative bacteria and exceedingly high serum protein binding. To overcome these drawbacks, which in the first instance could be related to the lipophilicity of compounds, either the introduction of a charged substituent on the phenyl ring ${ }^{1)}$, or an isosteric $\mathrm{CH} \rightarrow \mathrm{N}$ substitution within the ring was contrived. Using the latter approach, this paper presents the preparation and bioactivity of penems carrying at C-2 2-, 3-, or 4-pyridyl moieties as in $\mathbf{2 a \sim 2} \mathbf{c}$, and where the substitution on the pyridine ring was varied as in $\mathbf{2} \mathbf{d} \sim \mathbf{2} \mathbf{k}$.

Two quaternary ammonium derivatives (2l and $\mathbf{2 m}$ ) were also prepared. The po bioavailability was achieved through the preparation of an acetoxymethyl ester prodrug (4n; Fig. 2).

Fig. 1. Structure of penems $1 \mathbf{a}, \mathbf{1 b}$ and $\mathbf{2 a} \sim \mathbf{2 m}$.
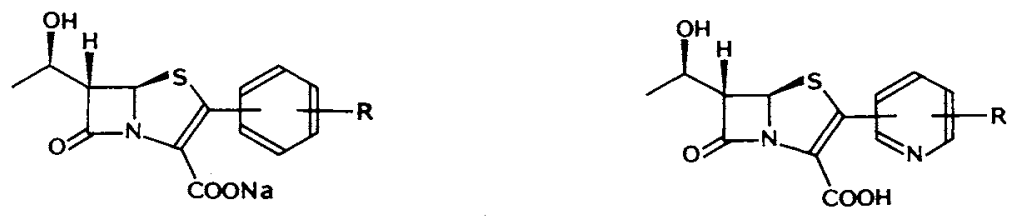

$\begin{array}{ll}\text { 1a } & \mathrm{R}=\mathrm{H} \\ \text { 1b } & \mathrm{R}=4-\mathrm{CH}_{3}\end{array}$<smiles>C[C@H](O)[C@H]1C(=O)N2C(C(=O)[O-])=C(c3ccc[n+](C)c3)SC12</smiles>

3-Pyridyl (2l)

4-Pyridyl (2m)

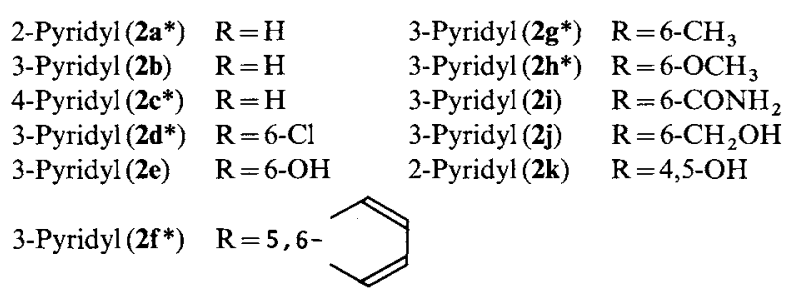

* Isolated as the sodium salt. 
Fig. 2. Structure of phosphoranes $\mathbf{3 a} \sim \mathbf{3 k}$ and penems $\mathbf{4 a} \sim \mathbf{4} \mathbf{k}$ and $\mathbf{4 n}$.
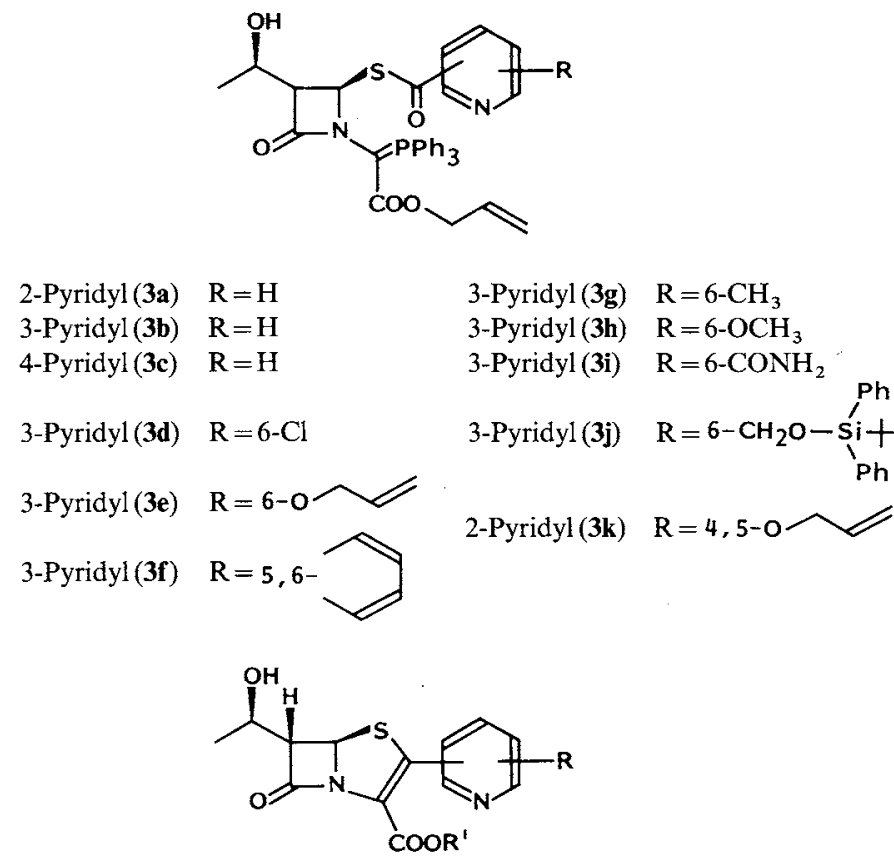

$\begin{array}{ll}\text { 2-Pyridyl (4a) } & \mathrm{R}=\mathrm{H} \\ \text { 3-Pyridyl (4b) } & \mathrm{R}=\mathrm{H} \\ \text { 4-Pyridyl (4c) } & \mathrm{R}=\mathrm{H} \\ \text { 3-Pyridyl (4d) } & \mathrm{R}=6-\mathrm{Cl} \\ \text { 3-Pyridyl (4e) } & \mathrm{R}=6-\mathrm{O}\end{array}$

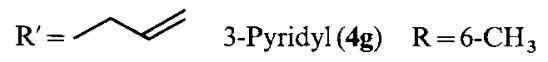<smiles>[R]CC=C</smiles>

3-Pyridyl (4h)

$\mathrm{R}=6-\mathrm{OCH}_{3}$<smiles>[R]CC=C</smiles>

3-Pyridyl

(4i) $\mathrm{R}=6-\mathrm{CONH}_{2}$<smiles>[R]CC=C</smiles>

3-Pyridyl (4j)<smiles>[R]=[SH]CO[Si](C)(P)c1ccccc1</smiles><smiles>[R]=CCC=C</smiles>

yl (4k)<smiles>[R][As]SOCC=C</smiles><smiles>[R]CC=C</smiles><smiles>[R]=CCC=C</smiles><smiles>[R]CC=C</smiles><smiles>[R]CC=C</smiles>

$\mathrm{R}^{\prime}=\mathrm{CH}_{2} \mathrm{OAc}$

\section{Chemistry}

Silver $(3 S, 4 R)$-1-[[allyloxy)carbonyl](triphenylphosphoranylidene)methyl]-3-[( $1 R$ )-hydroxyethyl]azetidin-2-one-4-thiolate, prepared by modification of a published procedure ${ }^{2)}$, was converted to the phosphorane thioesters 3a $\sim 3 \mathbf{k}$ (Fig. 2) by reaction with the appropriate pyridyl carboxylic chloride ( 2 mol equiv, $\mathrm{CH}_{2} \mathrm{Cl}_{2}$, $0^{\circ} \mathrm{C}$ to room temperature), in turn obtained from the corresponding potassium or sodium carboxylate $\left((\mathrm{COCl})_{2} \text {, benzene, room temperature }\right)^{3)}$.

Use of pyridines $5 \mathbf{a} \sim 7 \mathbf{a}$ required a protection-deprotection sequence (Fig. 3). Silver carbonate mediated reaction ${ }^{4)}$ of $5 \mathbf{a}$ and $\mathbf{6 a}^{5}$ ) with allyl bromide (benzene, room temperature, 24 hours) yielded the fully protected derivatives $\mathbf{5 b}$ and $\mathbf{6 b}$. Selective $O$-alkylation was demonstrated by ${ }^{1} \mathrm{H}$ NMR chemical shift of the pyridine $\alpha$-protons when compared with that of the tautomeric pyridone form ${ }^{\dagger}$. Ester hydrolysis (KOH 1 equiv, EtOH reflux, 2 hours) led to the potassium salts $5 \mathbf{c}$ and $6 \mathbf{c}$. tert-Butyldiphenylsilyl $O$-protection

+ Compare, for instance, the chemical shifts of the $\mathrm{H}_{\alpha}$ in $6 \mathbf{c}\left(8.50 \mathrm{ppm}\right.$ as free acid) and in $\mathbf{5 c}(8.50 \mathrm{ppm})$ vs the $\mathrm{H}_{\alpha}$ chemical shifts when the tautomeric pyridone forms are present $(7.40 \mathrm{ppm}$ in $6 \mathbf{a}$ and $8.05 \mathrm{ppm}$ in $5 \mathbf{a}$ sodium salt respectively). 
Fig. 3. Pyridines $5 a \sim 5 c, 6 a \sim 6 c$ and $7 a \sim 7 c$.<smiles>[R]OC(=O)c1ccc(O[R])nc1</smiles>

5a $\quad \mathrm{R}=\mathrm{R}^{\prime}=\mathrm{H}$

Sb $\quad R=R^{\prime}=$

5c $R=K \quad R^{1}=$<smiles>[R2]OC(=O)c1cc(O[R])c(O[R])cn1</smiles>

6a $\quad \mathrm{R}=\mathrm{R}^{\prime}=\mathrm{H}$

6b

6<smiles>[R]OCc1ccc(C(=O)O[R])cn1</smiles>

7a $\quad \mathrm{R}=\mathrm{R}^{\prime}=\mathrm{H}$

$7 \mathrm{~b} R=\mathrm{R}_{\mathrm{R}^{\prime}=\mathrm{H}}$

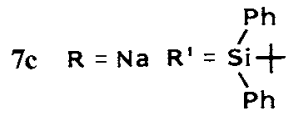

Table 1. In vitro antibacterial activity ${ }^{\mathrm{a}}$ of penems.

\begin{tabular}{|c|c|c|c|c|c|c|c|c|}
\hline Strain No. & $1 \mathbf{a}$ & $\mathbf{1 b}$ & $\mathbf{2 a}$ & $2 b$ & $2 c$ & 2d & $2 e$ & $2 f$ \\
\hline Staphylococcus aureus Smith & 0.19 & 0.04 & 0.19 & 0.09 & 0.09 & 0.02 & 0.02 & 0.01 \\
\hline S. aureus $39 / 2\left(\operatorname{Pen}^{+}\right)$ & 0.19 & 0.04 & 0.19 & 0.09 & 0.09 & 0.02 & 0.04 & 0.02 \\
\hline Streptococcus pyogenes ATCC 12384 & 0.04 & 0.02 & 0.19 & 0.02 & 0.01 & 0.02 & 0.04 & 0.001 \\
\hline S. faecalis ATCC 6057 & 3.1 & 3.1 & 6.2 & 1.5 & 3.1 & 0.78 & 1.5 & 0.78 \\
\hline Escherichia coli $\mathrm{K}-12$ & 12.5 & 12.5 & 0.78 & 0.78 & 3.1 & 1.5 & 0.78 & 6.2 \\
\hline E. coli $\mathrm{TEM}$ & 12.5 & 25 & 0.78 & 0.78 & 0.78 & 1.5 & 0.39 & 6.2 \\
\hline E. coli $\mathrm{B}$ & 0.78 & 0.39 & 0.78 & 0.78 & 1.5 & 0.39 & 0.78 & 0.02 \\
\hline Salmonella typhi ATCC 14028 & 3.1 & 6.2 & 0.78 & 0.39 & 1.5 & 0.78 & 0.39 & 6.2 \\
\hline Klebsiella aerogenes $1082 \mathrm{E}$ & 3.1 & 3.1 & 0.78 & 0.39 & 1.5 & 1.5 & 0.78 & 6.2 \\
\hline Enterobacter cloacae P 99 & 12.5 & 25 & 0.78 & 0.78 & 1.5 & 1.5 & 0.39 & 25 \\
\hline Citrobacter freundii ATCC 8090 & 3.1 & 3.1 & 0.78 & 0.39 & 1.5 & 0.78 & 0.78 & 6.2 \\
\hline
\end{tabular}

\begin{tabular}{|c|c|c|c|c|c|c|c|}
\hline Strain No. & $2 g$ & $\mathbf{2 h}$ & $2 \mathbf{i}$ & $2 \mathbf{j}$ & $2 \mathbf{k}$ & 21 & $2 \mathrm{~m}$ \\
\hline Staphylococcus aureus Smith & 0.02 & 0.02 & 0.09 & 0.04 & 0.09 & 0.09 & $>50$ \\
\hline S. aureus $39 / 2\left(\mathrm{Pen}^{+}\right)$ & 0.02 & 0.02 & 0.09 & 0.04 & 0.09 & 0.09 & $>50$ \\
\hline Streptococcus pyogenes ATCC 12384 & 0.01 & 0.09 & 0.09 & 0.01 & 0.01 & 0.02 & $>50$ \\
\hline S. faecalis ATCC 6057 & 1.5 & 1.5 & 1.5 & 1.5 & 1.5 & 25 & $>50$ \\
\hline Escherichia coli $\mathrm{K}-12$ & 0.39 & 1.5 & 0.78 & 0.39 & 1.5 & 12.5 & $>50$ \\
\hline E. coli TEM & 0.39 & 0.78 & 0.39 & 0.19 & 3.1 & 12.5 & $>50$ \\
\hline E. coli $\mathrm{B}$ & 0.19 & 0.19 & 0.39 & 0.19 & 0.78 & 12.5 & $>50$ \\
\hline Salmonella typhi ATCC 14028 & 0.39 & 1.5 & 0.39 & 0.19 & 1.5 & 25 & $>50$ \\
\hline Klebsiella aerogenes $1082 \mathrm{E}$ & 0.19 & 0.39 & 0.39 & 0.19 & 1.5 & 12.5 & $>50$ \\
\hline Enterobacter cloacae P 99 & 0.78 & 1.5 & 0.78 & 0.78 & 1.5 & 6.2 & $>50$ \\
\hline Citrobacter freundii ATCC 8090 & 0.19 & 0.39 & 0.39 & 0.39 & 1.5 & 6.2 & $>50$ \\
\hline
\end{tabular}

a MICs $(\mu \mathrm{g} / \mathrm{ml})$ were determined by the standard 2-fold agar dilution method in Mueller-Hinton Agar (Difco). Spots of $10^{4}$ bacteria were automatically applied to the surface of the agar using a multipoint inoculator.

was used in the synthesis of $\mathbf{2 j}$. Selective silylation of the benzylic hydroxyl required preventive esterification of $7 \mathbf{a}$ (chloroacetone, $N, N$-dimethylformamide, triethylamine, overnight). Reaction of $7 \mathbf{b}$ with tert-butyldiphenylsilyl chloride ( $3 \mathrm{~mol}$ equiv, imidazole 10 mol equiv, $\mathrm{CH}_{2} \mathrm{Cl}_{2}$, few minutes) and mild alkaline hydrolysis (KOH $1.2 \mathrm{~mol}$ equiv, $\mathrm{CH}_{3} \mathrm{CN}-\mathrm{H}_{2} \mathrm{O}, 10^{\circ} \mathrm{C}, 2$ hours) led to the desired $O$-protected reagent $7 \mathbf{c}$.

Heating of phosphoranes thioesters 3a $\sim 3 \mathbf{k}$ (benzene, reflux, $8 \sim 12$ hours) uneventfully afforded penem allyl esters $\mathbf{4 a} \sim \mathbf{4 k}$, which were deblocked with tetrakis(triphenylphosphine)palladium to $\mathbf{2 a} \sim \mathbf{2 k}$ as sodium salts or free acids, depending upon conditions (see Experimental part). The quaternary ammonium derivatives $\mathbf{2 l}$ and $\mathbf{2 m}$ were prepared simply by mixing the phosphoranes $\mathbf{3 b}, \mathbf{3} \mathbf{c}$ with $\mathrm{MeI}(\mathrm{MeCN}$, room 
Table 2. Pharmacokinetics parameters ${ }^{a}$ and DHP-I stability ${ }^{b}$ of penems.

\begin{tabular}{|c|c|c|c|c|c|c|c|c|c|c|c|c|c|}
\hline & $1 \mathbf{a}$ & 1b & $\mathbf{2 a}$ & $\mathbf{2 b}$ & $2 c$ & $2 d$ & $2 e$ & $2 f$ & $2 g$ & $\mathbf{2 h}$ & $2 \mathbf{i}$ & 2l & $4 n$ \\
\hline $\mathrm{t}_{1 / 2} \beta$ (minutes) & 13 & 8 & $>3$ & 5.5 & 4 & $>3$ & 3 & 14 & 3 & 8 & 7.5 & - & 14 \\
\hline AUC $(\mu \mathrm{g} / \mathrm{minute} / \mathrm{ml})$ & 2,209 & 748 & 286 & 268 & 692 & 286 & 146 & 928 & - & 667 & 251 & - & 180 \\
\hline po absorption ${ }^{\mathrm{c}}(\%)$ & 13 & 72 & $<1$ & $<1$ & 1.3 & 一 & - & - & - & - & - & - & 67 \\
\hline DHP-I stability ${ }^{\mathrm{d}}$ & 95.5 & - & - & $91.5^{\mathrm{e}}$ & - & - & 89.5 & - & 73 & - & - & 98.7 & - \\
\hline
\end{tabular}

a After iv administration at $10 \mathrm{mg} / \mathrm{kg}$ in mice, with the exception of $\mathbf{4 n}$, which was administered orally.

b $\%$ of unreacted starting material after 1 hour incubation of $30 \mu \mathrm{g} / \mathrm{ml}$ of penem and $1 \mu \mathrm{g} / \mathrm{ml}$ of purified porcine renal enzyme, at $37^{\circ} \mathrm{C}$, pH 7.1 MOPS buffer.

c $\left([\mathrm{AUC}]_{\mathrm{po}} /[\mathrm{AUC}]_{\mathrm{iv}}\right) \times 100$.

d Corresponding data for imipenem, taken as a reference compound, was 14 .

e At $100 \mu \mathrm{g} / \mathrm{ml}$.

Table 3. Therapeutic efficacy in mice of isosteric 2-phenyl and 2-pyridyl penems.

\begin{tabular}{|c|c|c|c|c|c|}
\hline \multirow{2}{*}{ Organism } & \multicolumn{5}{|c|}{$\mathrm{ED}_{50}{ }^{\mathrm{a}}(\mathrm{mg} / \mathrm{kg})$} \\
\hline & 1a & 1b & $\mathbf{2 b}$ & $2 g$ & $4 n$ \\
\hline Staphylococcus aureus Smith $^{\mathrm{b}}$ & $\gg 1$ & $\gg 1$ & $<0.16$ & $\begin{array}{c}0.32 \\
(0.08 \sim 1.21)\end{array}$ & $\begin{array}{c}0.47 \\
(0.17 \sim 1.3)\end{array}$ \\
\hline $\begin{array}{l}\text { Streptococcus pyogenes } 3 \\
\text { ATCC } 12384^{b}\end{array}$ & 一 & - & - & $\begin{array}{c}0.3 \\
(0.02 \sim 3.6)\end{array}$ & $\begin{array}{c}0.55 \\
(0.21 \sim 1.44)\end{array}$ \\
\hline Escherichia coli $\mathrm{G}^{\mathrm{e}}$ & - & - & $\begin{array}{c}7.6 \\
(5.5 \sim 10.4)\end{array}$ & $\begin{array}{c}6.4 \\
(4.97 \sim 5.36)\end{array}$ & $\begin{array}{c}16.33 \\
(12.24 \sim 21.8)\end{array}$ \\
\hline
\end{tabular}

a Confidence limits for $P=0.95$.

b Treatment: 2 hours after challenge.

c Treatments: $0.5,1.5$ and 6 hours after challenge.

temperature, overnight). Quaternarization at the pyridine nitrogen resulted, in fact, in thioester carbonyl activation sufficient for spontaneous Wittig reaction, which, after palladium mediated deallylation, gave zwitterions $\mathbf{2 l}$ and $\mathbf{2 m}$. As the compounds synthesized exhibited no significant po absorption as such, the ester prodrug $4 \mathrm{n}$ was prepared by reaction of $\mathbf{2 b}$ (sodium carboxylate) with acetoxymethyl bromide ( $0.9 \mathrm{~mol}$ equiv, $N, N$-dimethylformamide, $-20^{\circ} \mathrm{C}$, overnight).

\section{Biological Results and Discussion}

According to our expectations, replacement of the 2-phenyl ring of 1a with pyridine indeed increased activity against Gram-negative organisms, while retaining a remarkable potency against Gram-positive strains.

Among the unsubstituted pyridyl penems $2 \mathbf{a} \sim 2 \mathbf{c}$ the $m$-isomer proved the most active. In spite of major differences in electronic and polarity parameters, ring substitution in $\mathbf{2} \mathbf{d} \sim \mathbf{2 k}$ did not significantly affect intrinsic activity. Hammet $\sigma$ values of the ring substituent fairly correlated with chemical reactivity ${ }^{6}$ ) (data not shown) but not with antimicrobial activity; on the contrary the most reactive compounds (2l and $\mathbf{2 m}$ ), where the pyridine is quaternarized, proved poorly or not active. Low outer membrane permeation accounts for the narrow spectrum of the quinoline derivative $\mathbf{2 f}$. Compound $\mathbf{2 f}$, in fact, in spite of its excellent activity on Gram-positive bacteria and Escherichia coli B (a Gram-negative strain characterized by reduced permeability barriers), resulted poorly active on $E$. coli $\mathrm{K}-12$ and most Gram-negative organisms. Pharmacokinetic parameters of 2-pyridyl penems in mice are reported in Table 2.

The compounds showed plasma half-lives equal or superior to that displayed by our clinical candidate FCE 22101, and variable AUC values (Table 2). More interestingly, they retained most of the DHP-I 
stability characteristic of the 2-phenyl derivative 1a, which stands as one of the most stable penems in our in vitro hydrolysis experiments utilizing the purified porcine renal enzyme ${ }^{7)}$. The in vivo activity in mice of compounds $\mathbf{2 b}$ and $2 \mathrm{~g}$ is reported in Table 3; against Staphylococcus aureus and E. coli infections, $\mathbf{2 b}$ and $\mathbf{2 g}$ showed strong therapeutic efficacy, in contrast with the isosteric compounds of the phenyl series, 1a and $\mathbf{1 b}$, which were probably affected by an exceedingly high protein binding. The acetoxymethyl ester 4n, characterized by a high po bioavailability $(67 \%)$, associated with good therapeutic efficacy, should deserve further evaluation.

\section{Experimental}

IR spectra were recorded on a Perkin-Elmer 457 or 1420 IR spectrophotometer. FAB-MS were recorded on a Varianmat 311/A mass spectrometer equipped with a combined EI/FI/FD ion source. ${ }^{1} \mathrm{H}$ NMR were recorded at $200 \mathrm{MHz}$ on a Varian XL-200 spectrometer. UV spectra were recorded on a Farmitalia-Carlo Erba Strumentazione UV Spectracomp 301 spectrophotometer.

\section{In Vitro Antibacterial Activity}

MICs were determined by the standard 2-fold serial dilution method in Mueller-Hinton agar (Difco). Plates were inoculated with $10^{4} \mathrm{cfu} /$ spot using a multipoint inoculator (Denley Instruments Ltd., Bolney, Sussex). MICs were read after 18 hours of incubation at $37^{\circ} \mathrm{C}$ as the lowest concentration that inhibited visible growth.

Therapeutic Activity in Experimental Infections in Mice

Protection tests were done in female albino CD-1 COBS mice, weighting $21 \sim 23 \mathrm{~g}$, experimentally infected with $S$. aureus, Streptococcus pyogenes and $E$. coli. Mice were challenged by the ip route. Seven animals were used at each of the dose concentrations of antibiotic tested, which were given subcutaneously (compounds $1 \mathrm{a}, \mathbf{1 b}, \mathbf{2 b}$ and $\mathbf{2 g}$ ) or orally (compound $\mathbf{4 n}$ ) at $0.1 \mathrm{mg} / 10 \mathrm{~g}$ weight concentration. The mortality was recorded daily and the number of animal surviving on day 5 was used to calculate the median $\mathrm{ED}_{50}$.

\section{Phosphoranes 3a $\sim$ 3k}

General Preparation Method e.g. 3b: 3-Pyridyl carboxylic chloride $(2.73 \mathrm{~g})$ in abs $\mathrm{CH}_{2} \mathrm{Cl}_{2}(50 \mathrm{ml})$ was added dropwise to a stirred solution of silver $(3 S, 4 R)$-1-[[(allyloxy)carbonyl](triphenylphosphoranylidene)methyl]-3-[(1R)-hydroxyethyl]azetidin-2-one-4-thiolate $(5.97 \mathrm{~g})$ in abs $\mathrm{CH}_{2} \mathrm{Cl}_{2}(200 \mathrm{ml})$ containing pyridine $(100 \mu \mathrm{l})$ at $5^{\circ} \mathrm{C}$. After 10 minutes the cooling bath was removed and the reaction mixture was stirred for additional 15 minutes. Ethyl acetate $(150 \mathrm{ml})$ was added and the suspension was filtered through a filter-aid bed. The organic solution was washed with aq $\mathrm{NaHCO}_{3}$ and brine, then dried $\left(\mathrm{Na}_{2} \mathrm{SO}_{4}\right)$ and evaporated in vacuo to give after $\mathrm{SiO}_{2}$ chromatography with $n$-hexane-EtOAc (from 50:50 to 0:100) followed by EtOAc-acetone $(90: 10)$ the phosphorane thioester $3 \mathrm{~b}(3.2 \mathrm{~g})$ : IR $\left(\mathrm{CHCl}_{3}\right) \mathrm{cm}^{-1} 1750,1680$, 1610.

Potassium 4,5-Diallyloxypyridine-2-carboxylate 6c: 4,5-Dihydroxypyridine-2-carboxylic acid (6a) $(1.85 \mathrm{~g})$ and $\mathrm{Ag}_{2} \mathrm{CO}_{3}(11 \mathrm{~g})$ were suspended in benzene $(40 \mathrm{ml})$ at room temperature and allyl bromide $(15 \mathrm{ml})$ was added. The reaction mixture was stirred for 30 hours in the dark. The suspension was diluted with benzene $(40 \mathrm{ml})$ and filtered through a Celite bed. The solution was evaporated in vacuo to give, after silica gel column chromatography ( $n$-hexane - EtOAc, $60: 40$ ) allyl 4,5-diallyloxypyridine-2-carboxylate $6 \mathrm{~b}$ $(1.67 \mathrm{~g})$. To the ester dissolved in $\mathrm{EtOH} 95 \%(80 \mathrm{ml}), \mathrm{KOH}(420 \mathrm{mg})$ was added and the solution was refluxed for 2 hours. EtOH was concentrated in vacuo to $20 \mathrm{ml}, \mathrm{Et}_{2} \mathrm{O}(100 \mathrm{ml})$ was added and the insoluble potassium salt $6 \mathbf{c}(1.53 \mathrm{~g})$ was obtained after filtration and drying in vacuo: ${ }^{1} \mathrm{H}$ NMR as free acid (DMSO- $\left.d_{6}\right)$ $\delta 4.8\left(2 \mathrm{H}, \mathrm{m}, \mathrm{CH}_{2}\right), 5.27 \sim 5.47\left(2 \mathrm{H}, \mathrm{m}, \mathrm{CH}_{2}\right), 5.95 \sim 6.13(1 \mathrm{H}, \mathrm{m}, \mathrm{CH}), 7.67(1 \mathrm{H}, \mathrm{s}$, aromatic $\mathrm{CH}), 8.27$ $(1 \mathrm{H}, \mathrm{s}$, aromatic $\mathrm{CH})$. In the same way potassium 6-allyloxypyridine-3-carboxylate $5 \mathrm{c}$ was obtained: ${ }^{1} \mathrm{H}$ NMR (DMSO-d $\left.d_{6}\right) \delta 4.78\left(2 \mathrm{H}, \mathrm{m}, \mathrm{CH}_{2}\right), 5.2 \sim 5.4\left(2 \mathrm{H}, \mathrm{m}, \mathrm{CH}_{2}\right), 5.95 \sim 6.15(1 \mathrm{H}, \mathrm{m}, \mathrm{CH}), 6.63(1 \mathrm{H}, \mathrm{d}$, aromatic $\mathrm{CH}), 7.98(1 \mathrm{H}$, dd, aromatic $\mathrm{CH}), 8.48(1 \mathrm{H}$, d, aromatic $\mathrm{CH})$.

Sodium 6-tert-Butyldiphenylsilyloxymethylpyridine-3-carboxylate 7c: To a solution of potassium 
6-hydroxymethylpyridine-3-carboxylate $7 \mathbf{a}$, prepared by a modification of a published procedure ${ }^{8)}, 2.4 \mathrm{~g}$ in DMF (20 ml) chloroacetone $(1 \mathrm{ml})$ was added at room temperature. The solution was stirred for 28 hours and then concentrated in vacuo. The residue was taken up in EtOAc $-\mathrm{H}_{2} \mathrm{O}$, the organic layer was dried $\left(\mathrm{Na}_{2} \mathrm{SO}_{4}\right)$ and evaporated in vacuo to give crude $7 \mathbf{b}$. The crude oil was dissolved in $\mathrm{CH}_{2} \mathrm{Cl}_{2}(70 \mathrm{ml})$ and imidazole $(1.6 \mathrm{~g})$ and tert-butyldiphenylsilyl chloride were successively added at $0{ }^{\circ} \mathrm{C}$ while stirring. After 15 minutes, the suspension was poured in water. The organic phase was separated, washed with brine, dried $\left(\mathrm{Na}_{2} \mathrm{SO}_{4}\right)$, concentrated in vacuo, and purified by $\mathrm{SiO}_{2}$ chromatography eluting with $n$-hexane-EtOAc mixtures to give acetonyl 6-tert-butyldiphenylsilyloxymethylpyridine-3-carboxylate $(2.6 \mathrm{~g})$. The diprotected pyridine was dissolved in $\mathrm{MeCN}(20 \mathrm{ml})$ and water $(6 \mathrm{ml})$ and $\mathrm{NaOH} 0.4 \mathrm{M}(15 \mathrm{ml})$ was added dropwise during 1 hour (TLC monitoring). The solution was concentrated in vacuo to small volume, toluene was added $(2 \times 100 \mathrm{ml})$ and the solution evaporated twice in vacuo. The waxy solid was taken up in acetone $(20 \mathrm{ml})$ and $n$-hexane $(70 \mathrm{ml})$. The acetonic layer was evaporated in vacuo to dryness to give $7 \mathrm{c}$ as a foam $(2.3 \mathrm{~g}):{ }^{1} \mathrm{H}$ NMR (DMSO- $\left.d_{6}\right) \delta 1.03\left(9 \mathrm{H}, \mathrm{s}, \mathrm{CH}_{3}\right), 4.76\left(2 \mathrm{H}, \mathrm{s}, \mathrm{CH}_{2}\right), 7.3 \sim 7.7(11 \mathrm{H}$, $\mathrm{m}$, aromatic $\mathrm{CH}), 8.13(1 \mathrm{H}$, dd, aromatic $\mathrm{CH}), 8.8(1 \mathrm{H}$, d, aromatic $\mathrm{CH})$.

\section{Penems Esters 4a $\sim$ 4k: General Preparation Method e.g. 4b}

A stirred solution of phosphorane $3 \mathrm{~b}(3.2 \mathrm{~g})$ in benzene $(20 \mathrm{ml})$ was refluxed for 8 hours. The solvent was removed in vacuo and the residue chromatographed with $n$-hexane - EtOAc $(30: 70)$ to yield the penem $4 \mathbf{b}(1.63 \mathrm{~g})$, contaminated with some $\mathrm{Ph}_{3} \mathrm{PO}$, as an oil: IR $\left(\mathrm{CHCl}_{3}\right) \mathrm{cm}^{-1} 1780,1720 ;{ }^{1} \mathrm{H}$ NMR $(90 \mathrm{MHz}$, $\left.\mathrm{CDCl}_{3}\right) \delta 1.33\left(3 \mathrm{H}, \mathrm{d}, \mathrm{CH}_{3}\right), 3.75(1 \mathrm{H}, \mathrm{dd}, \mathrm{CH}), 4.5(1 \mathrm{H}, \mathrm{m}, \mathrm{CH}), 4.85\left(2 \mathrm{H}, \mathrm{m}, \mathrm{CH}_{2}\right), 5.2 \sim 5.6(2 \mathrm{H}, \mathrm{m}$, $\left.\mathrm{CH}_{2}\right), 5.9(1 \mathrm{H}, \mathrm{m}, \mathrm{CH}), 6.45(1 \mathrm{H}, \mathrm{d}, \mathrm{CH}), \sim 7.4(1 \mathrm{H}, \mathrm{m}$, aromatic $\mathrm{CH}), 8.05(1 \mathrm{H}, \mathrm{m}$, aromatic $\mathrm{CH})$, $8.8 \sim 8.9(1 \mathrm{H}, \mathrm{m}$, aromatic $\mathrm{CH}), 9.1(1 \mathrm{H}, \mathrm{d}$, aromatic $\mathrm{CH})$.

\section{Penem Acids 2b, 2e, 2i $\sim 2 \mathbf{j}:$ General Deprotection Procedure}

Penem 2b: To a stirred solution of penem ester $4 \mathbf{b}(650 \mathrm{mg})$ in $\mathrm{CH}_{2} \mathrm{Cl}_{2}-\mathrm{THF}(1: 1)$ (80 ml) glacial acetic acid $(0.8 \mathrm{ml}), \mathrm{Ph}_{3} \mathrm{P}(280 \mathrm{mg})$, and $\left(\mathrm{Ph}_{3} \mathrm{P}\right)_{4} \mathrm{Pd}(280 \mathrm{mg})$ were added. The reaction mixture was stirred at room temperature for 30 minutes, then $\mathrm{Et}_{2} \mathrm{O}(40 \mathrm{ml})$ was added. The precipitate was collected by centrifugation and purified by reverse phase chromatography (LiChroprep RP-18) eluting with water - acetone (95:5). The UV active fractions were collected and concentrated in vacuo to small volume. The white precipitate was collected by filtration and dried in vacuo to yield $\mathbf{2 b}$ as an amorphous solid $\left(330 \mathrm{mg}\right.$ ), $\mathrm{mp} 205 \sim 208^{\circ} \mathrm{C}(\mathrm{dec})$. Spectral data are collected in Table 4.

\section{Penems Sodium Salts 2a, 2c, 2d, 2f $\sim 2 \mathbf{h}$ : General Deprotection Procedure}

Penem 2a: To a stirred solution of penem ester $\mathbf{4 a}(1.03 \mathrm{~g})$ in $\mathrm{THF}-\mathrm{CH}_{2} \mathrm{Cl}_{2}(1: 1)(70 \mathrm{ml}) \mathrm{Ph}_{3} \mathrm{P}$ (200 mg), sodium 2-ethylhexanoate $(410 \mathrm{mg})$ and $\left(\mathrm{Ph}_{3} \mathrm{P}\right)_{4} \mathrm{Pd}(200 \mathrm{mg})$ were sequentially added. The mixture was stirred at room temperature for 30 minutes and, after dilution with $\mathrm{Et}_{2} \mathrm{O}(200 \mathrm{ml})$, the precipitated salt was collected by centrifugation, dissolved in water and chromatographed (LiChroprep RP-18) eluting with water. The appropriate fractions were collected and freeze-dried to give the title compound ( $453 \mathrm{mg})$. Spectral data are collected in Table 4.

Penem 2k: To a stirred solution of the penem $4 \mathbf{k}(200 \mathrm{mg})$ in THF $-\mathrm{CH}_{2} \mathrm{Cl}_{2}(1: 1)(20 \mathrm{ml}) \mathrm{Ph}_{3} \mathrm{P}(35 \mathrm{mg})$, sodium 2-ethylhexanoate $(31 \mathrm{mg})$, glacial acetic acid $(0.3 \mathrm{ml})$, and $\left(\mathrm{Ph}_{3} \mathrm{P}\right)_{4} \mathrm{Pd}(200 \mathrm{mg})$ were added successively. The mixture was stirred at room temperature for 30 minutes and, after dilution with $\mathrm{Et}_{2} \mathrm{O}$ $(200 \mathrm{ml})$, the precipitated salt was collected by centrifugation, dissolved in water and chromatographed on reverse phase (LiChroprep RP-18) eluting with water - acetone $(9: 1)$ to give $125 \mathrm{mg}$ of the title compound.

Acetoxymethyl $(5 R, 6 S)-6-[1(R)$-Hydroxyethyl]-2-(3-pyridyl)penem-3-carboxylate $\mathbf{4 n}$

A solution of acetoxymethyl bromide (125 mg) in DMF (1 ml) was added to a solution of $2 \mathrm{~b}(320 \mathrm{mg})$ in DMF $(8 \mathrm{ml})$ at $-20^{\circ} \mathrm{C}$ under stirring. After 2.5 hours stirring another portion of acetoxymethyl bromide $(75 \mathrm{mg})$ in DMF $(5 \mathrm{ml})$ was added. Stirring was continued overnight. The reaction mixture was poured in EtOAc - water and the organic layer washed twice with brine, dried over anhydrous $\mathrm{Na}_{2} \mathrm{SO}_{4}$, filtered and evaporated in vacuo. The oily residue was chromatographed on $\mathrm{SiO}_{2}$ eluting with $n$-hexane - EtOAc mixtures 
Table 4. Spectroscopic data of penem compounds $\mathbf{1 a}, \mathbf{1 b}$ and $\mathbf{2 a} \sim \mathbf{2 k}$.

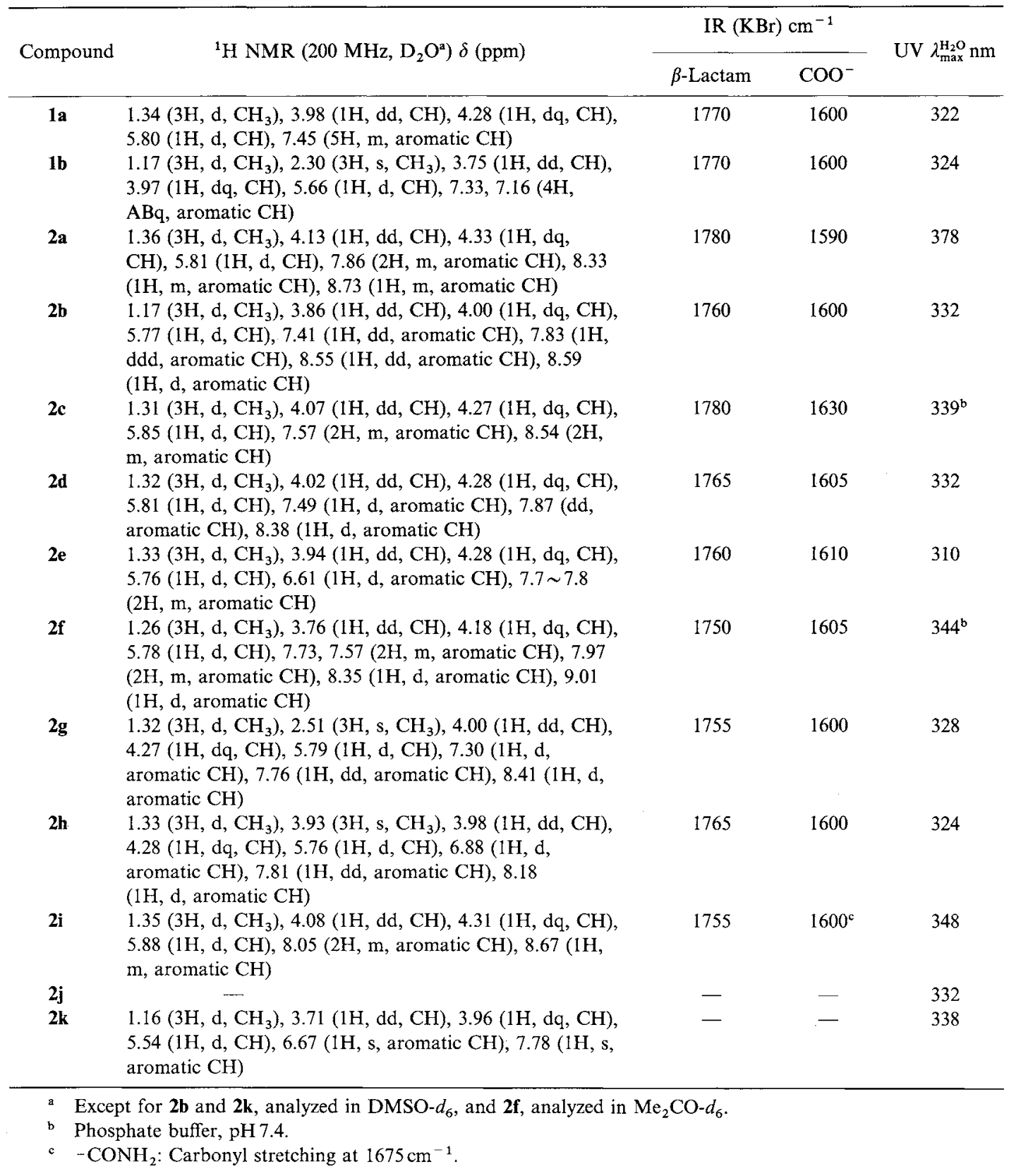

to yield the title product as a foam $(220 \mathrm{mg})$ : IR $\left(\mathrm{CHCl}_{3}\right) \mathrm{cm}^{-1} 1785,1760(\mathrm{sh}), 1720$; UV $\lambda_{\max }^{\mathrm{H}_{2} \mathrm{O}} \mathrm{nm} 340$; ${ }^{1} \mathrm{H}$ NMR $\left(200 \mathrm{MHz}, \mathrm{CDCl}_{3}\right) \delta 1.38\left(3 \mathrm{H}, \mathrm{d}, \mathrm{CH}_{3}\right), 2.06\left(3 \mathrm{H}, \mathrm{s}, \mathrm{CH}_{3}\right), 3.85(1 \mathrm{H}, \mathrm{dd}, \mathrm{CH}), 4.29(1 \mathrm{H}, \mathrm{dq}$, $\mathrm{CH}), 5.69,5.74\left(2 \mathrm{H}, \mathrm{ABq}, \mathrm{CH}_{2}\right), 5.76(1 \mathrm{H}, \mathrm{d}, \mathrm{CH}), 7.33(1 \mathrm{H}, \mathrm{m}$, aromatic $\mathrm{CH}), 7.81(1 \mathrm{H}, \mathrm{m}$, aromatic $\mathrm{CH}), 8.6 \sim 8.7(2 \mathrm{H}, \mathrm{m}$, aromatic $\mathrm{CH})$.

$(5 R, 6 S)-6-[(1 R)-1$-Hydroxyethyl]-2-(1-methyl-3-pyridinium)penem-3-carboxylate (2l):

To a solution of $\mathbf{3 b}(500 \mathrm{mg})$ in $\mathrm{MeCN}(10 \mathrm{ml})$ an excess of MeI $(1 \mathrm{ml})$ was added and the mixture was let stand overnight. The solution was then evaporated in vacuo and the crude product was purified by $\mathrm{SiO}_{2}$ column chromatography eluting with EtOAc-hexane mixtures, to give $300 \mathrm{mg}$ of the allyl ester 
of the title compound (as iodide). This compound was deprotected as described above for penem $\mathbf{2 b}$. After purification by reverse phase column the UV active fractions were collected and lyophilized to yield zwitterion 2l. IR $(\mathrm{KBr}) \mathrm{cm}^{-1} 1770,1595 ;{ }^{1} \mathrm{H}$ NMR $\left(200 \mathrm{MHz}, \mathrm{D}_{2} \mathrm{O}\right) \delta 1.33\left(3 \mathrm{H}, \mathrm{d}, \mathrm{CH}_{3}\right), 4.11(1 \mathrm{H}, \mathrm{dd}$, $\mathrm{CH}), 4.30(1 \mathrm{H}, \mathrm{dq}, \mathrm{CH}), 4.39\left(3 \mathrm{H}, \mathrm{s}, \mathrm{CH}_{3}\right), 5.91(1 \mathrm{H}, \mathrm{d}, \mathrm{CH}), 8.01(1 \mathrm{H}, \mathrm{dd}$, aromatic $\mathrm{CH}), 8.54(1 \mathrm{H}, \mathrm{d}$, aromatic $\mathrm{CH}), 8.73(1 \mathrm{H}, \mathrm{d}$, aromatic $\mathrm{CH}), 8.96(1 \mathrm{H}, \mathrm{s}$, aromatic $\mathrm{CH}) ; \mathrm{UV} \lambda_{\max }^{\mathrm{H}_{2} \mathrm{O}} \mathrm{nm} \mathrm{338}$, mass spectrum (FAB): $m / z 307\left(100, \mathrm{MH}^{+}\right), 263\left(20, \mathrm{MH}^{+}-\mathrm{CO}_{2}\right)$.

\section{References}

1) Perrone, E.; M. Alpegiani, A. Bedeschi, F. Giudici, F. Zarini, G. Franceschi, C. Della Bruna, D. Jabes \& G. MeINARDI: Novel quaternary ammonium penems: The [(pyridinio)methyl]phenyl derivatives. J. Antibiotics 40: $1636 \sim 1639,1987$

2) Martel, A.; P. Dextraze, J. P. Daris, R. Saintonge, P. Lapointe, T. T. Conway, I. Monkovic, G. Kavadias, Y. Ueda, P. Elie, S. Patil, G. Caron, J. L. Douglas, M. Menard \& B. Belleau: Nuclear analogs of $\beta$-lactam antibiotics. XIV. Synthesis of penems via (4-tritylthio-2-azetidinon-1-yl)triphenylphosphoranylydeneacetates. Can. J. Chem. 60: 942 944, 1982

3) Castle, R. N. \& C. W. Whitrle: Synthesis of some 2-(3-indolylethenyl)- and 2-(2-pyrrylethenyl)-pyridines and hydrogenated analogs. J. Org. Chem. 24: $1189 \sim 1192,1959$

4) Mochida, K.; Y. Ono, M. Yamasaki, C. Shiraki, T. Hirata, K. Sato \& R. Okachi: Aminothiazolylglycyl derivatives of carbacephem antibiotics. II. Synthesis and antibacterial activity of novel aminothiazolyl cephem compounds with hydroxypyridone moiety. J. Antibiotics 40: 182 189, 1987

5) Chung, N. M.\& H. Tiecklemann: Alkylations of heterocyclic ambident anions. IV. Alkylation of 5-carbetoxy- and 5-nitro-2-pyridone salts. J. Org. Chem. 35: $2517 \sim 2520,1970$

6) Bedeschi, A.; G. Visentin, E. Perrone, G. Franceschi, G. Meinardi, P. Castellani, D. Jabes \& C. Della BRUNA: Structure-activity relations in the class of 2-pyridylpenems. Program and Abstracts of the 28th Intersci. Conf. on Antimicrob. Agents Chemother., No. 226, p. 149, Los Angeles, Oct. $23 \sim 26,1988$

7) Cassinelli, G.; R. Corigli, P. Orezzi, G. Ventrella, A. Bedeschi, E. Perrone, D. Borghi \& G. Franceschi: Structure determination of the primary renal metabolite of the penem FCE 22101. J. Antibiotics 41: 984 987, 1988

8) Baker, W.; K. M. Buggle, J. F. W. MCOmie \& D. A. M. Watkins: Attemps to prepare new aromatic systems. Part VII. 15: 16-dihydro-15: 16-diazapyrene. The synthesis of di(pyridine-2:6-dimethylene). J. Chem. Soc. 1958: $3594 \sim 3603,1958$ 